\title{
Overlooked Imports: Carnelian Beads in the Korean Peninsula
}

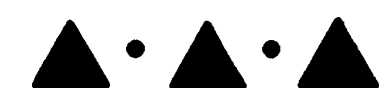

Lauren Glover and J. M. Kenoyer

\begin{abstract}
Analyses of a sample of 68 carnelian and agate beads from Korea's late Proto-Three Kingdoms and Three Kingdoms period (C.E. 100-668) provide evidence for longdistance exchange with South Asia. Three Kingdoms period elites were rejecting locally made stone beads made of local materials for stone beads obtained from long distance trade and made of non-local materials. Some of these beads may also be derived from South, Central, or Southeast Asia as well as from regions of modern China or Mongolia. The beads were recovered from burials at sites associated with the Paekche (RR: Baekje), Kaya (RR: Gaya), and Silla cultural traditions. There have been no local bead workshops found during the Three Kingdoms period and the carnelian beads were manufactured using different drilling technologies compared to earlier Korean drilling. Faceted hexagonal, spherical, and irregularly shaped carnelian beads were perforated using diamond drills, a technology originally developed in South Asia ca. 600 B.C.E. Quantitative analyses of drill hole size and overall size and shape of the beads points to multiple workshops supplying the imported beads. The distribution patterns of the beads in different polities may reflect changes in trade networks over time as well as stylistic choices of bead shapes used as a means of differentiating specific groups or individuals. Evidence for string wear and external weathering indicate that some beads were used for long periods of time enroute to Korea or in Korea itself before burial in mortuary contexts. KEYwORDs: trade, stone beads, drilling, carnelian, South Asia, Korea, Three Kingdoms period.
\end{abstract}

\section{INTRODUCTION}

ORNAMENTATION SUCH AS BEADS SERVE AS A VISUAL INDICATION of a person's wealth, status, ideology, or cultural affiliation (Baines and Yoffee 2000:13; Kenoyer 1995:90, 2000:88; Schortman and Urban 2004:189). These ornaments act as a socially understood symbol, which legitimates and affirms an individual's place in society. In ancient Korea, during the late Proto-Three Kingdoms (C.E. 1-300) and Three Kingdoms (C.E. 300-668) periods (Nelson 1993:173, 206), stone, glass, and gold beads were used by elites to show their social status and power (Kwon 2008:80; Park 2008:121, 131). These beads were often included in burial goods that were used to adorn the dead or placed as offerings in the tombs. Outside of mortuary contexts, they are sometimes found in ritual deposits.

Lauren Glover is a Ph.D. Candidate in Anthropology at University of Wisconsin-Madison. J. M. Kenoyer is Professor of Anthropology at University of Wisconsin-Madison. 
In this article, we present analyses of carnelian and agate beads from Korea's late Proto-Three Kingdoms and Three Kingdoms period (C.E. 100-668) that provide important new perspectives on the nature of elite trade networks connecting the Korean Peninsula with the distant regions of South Asia and Southeast Asia, as well as Central Asia and mainland East Asia. By the Three Kingdoms period, elites in the Korean peninsula were forsaking locally produced stone beads made of locally available materials for stone beads manufactured elsewhere with different technological methods that were reaching the peninsula via long distance trade. For this study, 123 stone beads, 68 of which are identified as carnelian and agate, were documented from selected elite burials at sites associated with the Paekche, Kaya, and Silla cultural traditions (Fig. 1). Beads were chosen due to their availability for analysis in either museum collections or recent site reports. The main focus will be on the carnelian beads that were found in burials of all three cultural traditions (Chungang 2013; Kukpang 2015; Kungnip 1993; Kyŏngbuk 2000; Kyŏnggi 2012; Kyŏre 2013;

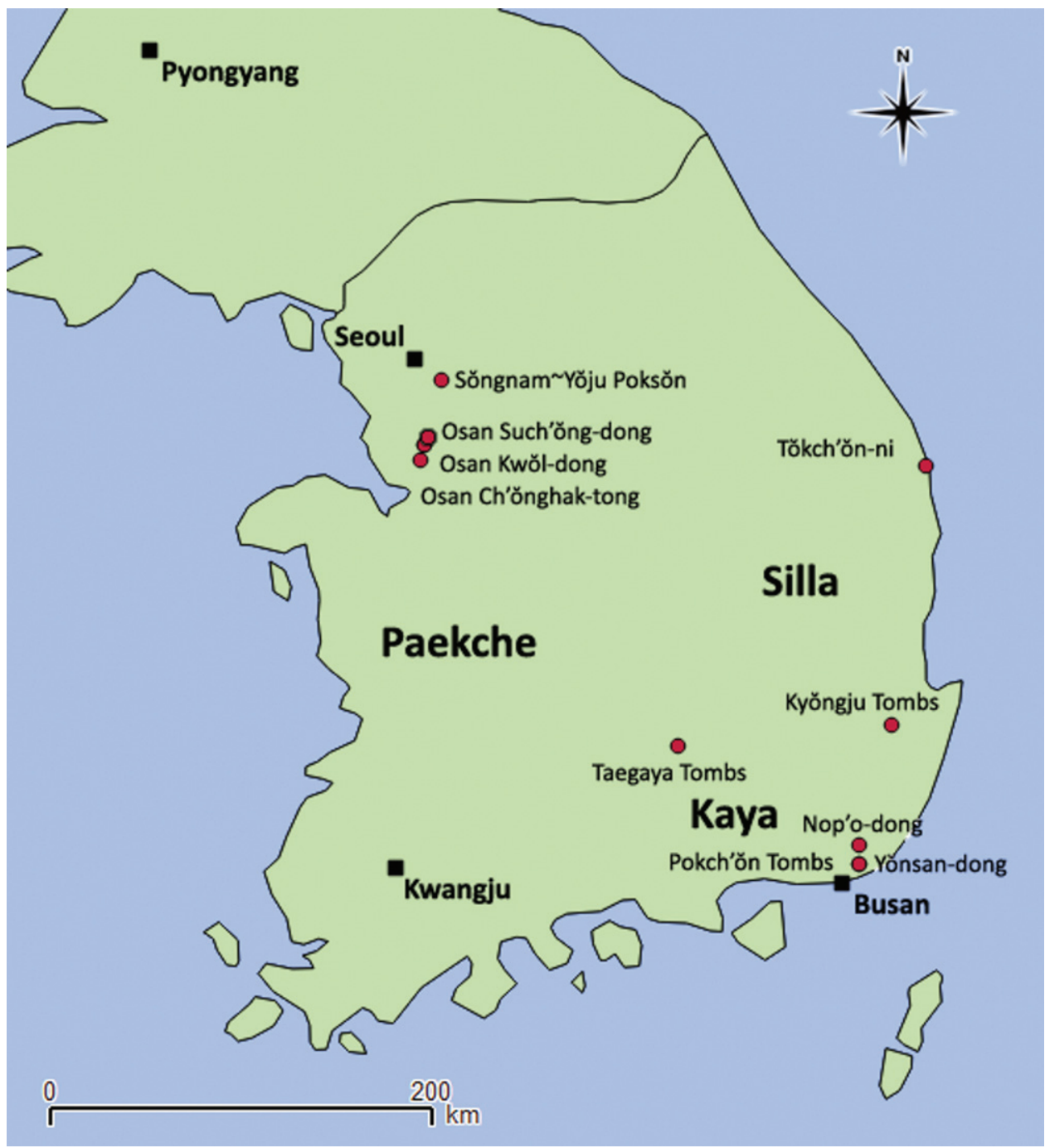

Fig. 1. Major sites and associated kingdoms. 
Pokch’ŏn 2013a, 2013b; Pusan Pangmulgwan 2014; Pusan Taehakkyo 1988, 2012; Sŏngnim 2014).

Detailed analyses of carnelian bead size and shape, as well as manufacturing features, indicate that the beads were produced using two major different drilling technologies and may have been produced in different workshops located in South Asia or some other region, but probably not on the Korean Peninsula since there have been no stone bead workshops found during the Three Kingdoms period. One drilling technique involves the use of diamond drills that were developed in and are linked to South Asian production centers, while the other technology involves the use of metal drills and fine abrasives. Numerous regions of Southeast, Central, and East Asia used metal drills and abrasives for perforating hard stone, so the identification of specific source areas is more difficult. However, even without knowing the specific source areas, it is possible that the distribution patterns of the beads in different polities, with certain polities utilizing different bead sources, may reflect changes in trade networks over time as well as stylistic choices of bead shapes used as a means of differentiating specific groups or individuals.

Locally produced stone beads, most notably of amazonite, were very prominent prior to the Three Kingdoms period (Pokch'ŏn 2013b:64-66). Rock crystal beads were also quite important during this period, but their place of origin is still uncertain. During the Three Kingdoms period, locally and externally produced glass beads (Pak 2016:140) and a variety of stone beads, particularly carnelian, become more common and gradually replace the use of amazonite and rock crystal (Pokch'ŏn 2013b). The dramatic increase of glass beads found in the Three Kingdoms period can be attributed to increased production internationally and the development of local glass production. There was also an increase in imported glass beads from South and Southeast Asia (Pak 2016:172). Carnelian beads also were not made locally since there are no locally available raw materials, and these beads continued to be imported and also possibly passed down from one generation to the next before they were finally placed in elite tombs. The continued use of carnelian beads in burial ornaments indicates that they still retained a significant role as indicators of wealth, ideology and cultural affiliation even though glass beads were relatively more common.

Assigning value to objects used in the past is a difficult prospect (Lesure 1999:24; Renfrew 2012:250). It is hard to determine if something that is considered valuable today was as important in the past since value is situationally mediated (Appadurai 1988:13-15). However, certain assumptions based on the availability of raw materials and the technological skill and time required for manufacture can be made to estimate the relative value of an artifact in relation to other artifacts (Kenoyer 2000:91). Rare or difficult to obtain raw materials tend to have more value than local ones and the value of an artifact generally increases based on the technological skill and time required to manufacture it. In the context of the Korean peninsula, carnelian beads, constructed of non-local material using advanced technological methods, appear to have been extremely valuable and were used exclusively by elites as symbols of wealth and power. These beads were buried along with other rare objects in elite burials and ritual contexts.

It is also important to note that foreign goods, obtained from long distance trade, can have a political and ideological symbolism which demonstrates the elite individuals 'skill' at both obtaining and utilizing the object (Helms 1993:4). Elites can also actively work to increase the value of their artifacts. For example, the Inka Empire switched to 
copper-tin alloys in order to curb local production since the Inkan state controlled the tin supply (Earle 1994:457). Korean elites may have made a similar decision to switch from locally available materials like amazonite to those only available by long distance trade and complex manufacturing processes in order to increase their value.

In order to better understand the ways in which elites in Korea might have obtained carnelian beads, it is first important to define the types of beads that were being used and their possible sources. The systematic methodology for recording and documenting stone beads is presented below, followed by a presentation of preliminary interpretations.

\section{STONE BEAD ANALYSES}

The study of stone beads at sites in Korea has a long history (Pokch'ŏn 2013a, 2013b; Takahashi 2012). This study builds on earlier work by combining the earlier approaches with methodologies that have been developed for the study of beads in South Asia (Kenoyer 2003, 2005, 2017a, 2017b, 2017c). The terminology and measurement system used in this study are presented here so that other scholars can clearly see how the beads were measured and quantified. Using a standardized approach to documentation allows for more meaningful comparative studies with multiple bead assemblages in Korea and other regions of Asia where beads were produced and traded.

\section{Raw Material}

Identification of raw materials is the most important and first step in the study of a bead; for stone beads, this requires visual examination to determine the nature of the rock and using Specific Gravity measurements to narrow down the type of rock. Carnelian is a light to dark red-orange color of micro-crystalline silicate that is part of a larger family of rocks called chalcedony. Its Specific Gravity ranges from 2.6 to 2.7 and hardness from 6.5 to 7 on the Mohs scale (Farrington and Laufer 1927; Pough 1988). Some carnelian, often called sardonyx, shows banding that is the result of the formation process in geodes. When the banding includes white, black, brown, or other colors, the rock is often called agate. In this study, the carnelian used to make the beads was relatively uniform in color, ranging from light, translucent red-orange to dark, semi opaque red-orange. In some beads it is possible to see banding that includes lighter redorange or translucent bands. Very uniformly colored red-orange carnelian beads can easily be misidentified as "glass," but most ancient glass is much softer than agate, has a lower Specific Gravity (2.3-2.4), and often has inclusions and bubbles that are visible to the naked eye or under minimal magnification.

\section{Measurements}

The measurements used by archaeologists to define specific sizes and shapes of beads are highly variable depending on the bead shape, but the main measurements include maximum and minimum proportions of length and width (or diameter); these measurements can be used to determine the degree of standardization and uniformity in shape production (Kenoyer 2017b:155-156) (Fig. 2). The measurement of the drill hole maximum diameter on both ends of a bead are also significant for determining the type of drill used and the distinctive technical features of different workshops. The drill 


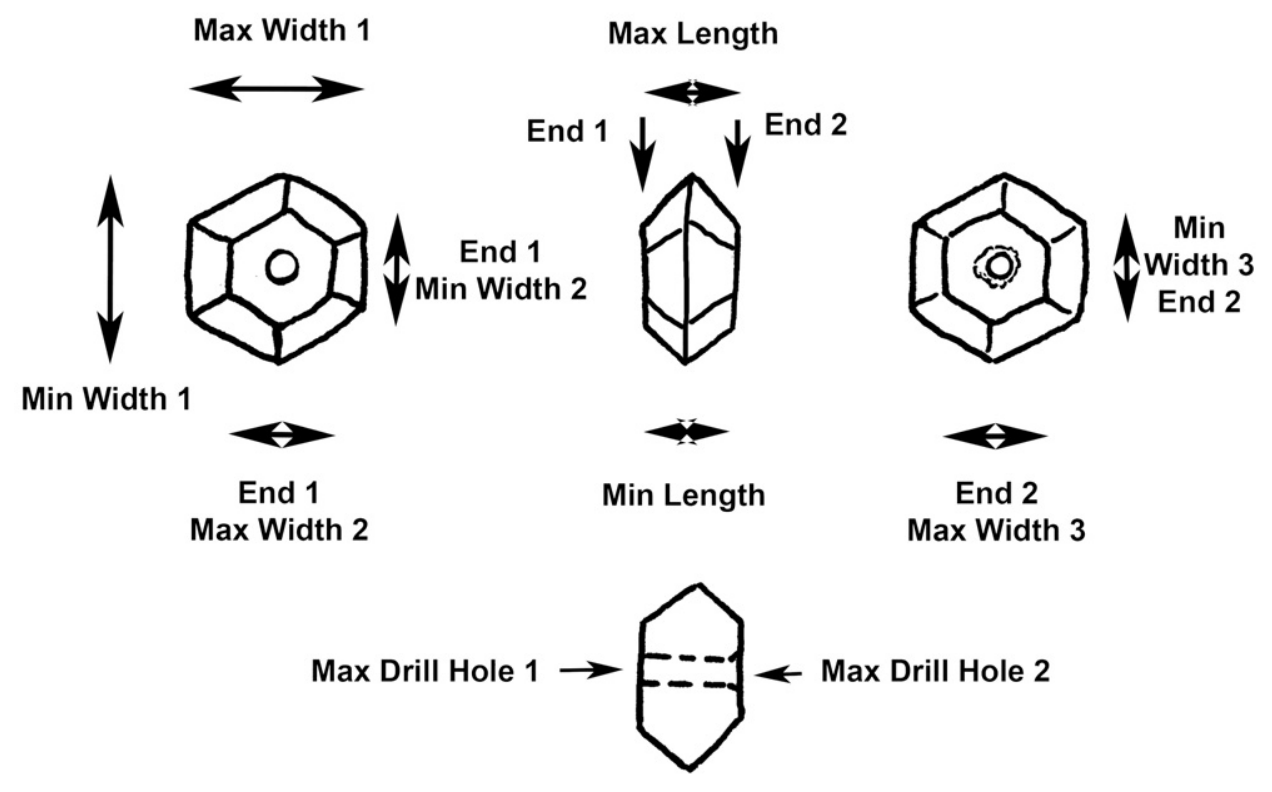

Fig. 2. Major bead measurements.

a.
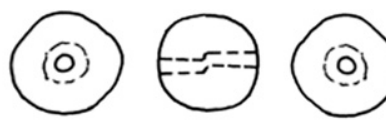

b.
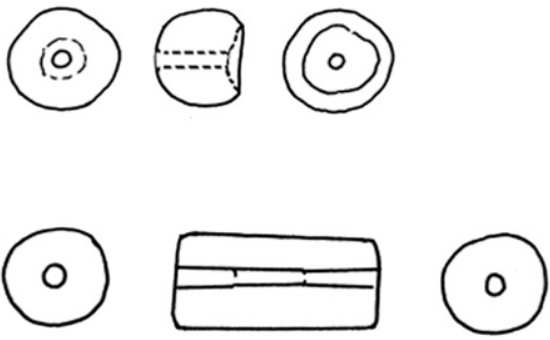

d.<smiles>C1CC2C3CC4CC(C3)C2CC14</smiles><smiles>C1=C2CCC3CCC1C3C2</smiles><smiles></smiles>

e.<smiles></smiles>

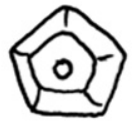

Fig. 3. Major drill hole types: (a) spherical, straight cylindrical drill hole, drilled from two sides, does not meet in the center; (b) irregular spherical, straight cylindrical drill hole, drilled from one side and popped out; (c) long cylindrical with slightly beveled ends, long tapered and stepped cylindrical drill hole, drilled from two sides, meets in center; (d) faceted, hexagonal bicone, straight cylindrical drill hole, drilled from one side and popped out; (e) faceted, pentagonal barrel, long tapered cylindrical, drilled from one side and popped out. 
hole diameters must also be analyzed in combination with the identification of the type of drilling in order compare bead types and manufacturing technologies (Kenoyer 2017b:161-162) (Fig. 3). In this study a large number of measurements were taken wherever possible in order to fully document variations in bead shape and manufacturing details.

\section{External Surface Descriptions}

When documenting the surface features of a bead, it is often possible to identify various stages of manufacture, wear that resulted from use, or post-depositional processes such as burning or staining in the soil (Kenoyer 2017b:156-159). Chipping and coarse grinding that takes place in the initial stages of production is usually removed by fine grinding and then final polishing. However, some beads were not made very carefully and traces of earlier stages of production are clearly visible on the surfaces (Fig. 4a, b). Chipping can also leave conical percussion scars that are deeply embedded in the rock, but become more visible over time and in the course of weathering. Wear that is seen on the edges of the drill hole is the result of the bead moving on a string and minute traces of silica dust abrading and polishing the surface (Fig. 4b). The ends of a bead can also show abrasion resulting from beads rubbing against each other on a necklace or ornament (Fig. 4b). When examining the interior drill hole impression using a Scanning Electron Microscope (SEM), it is also possible to see wear from the string and silt on the narrow areas of the drill hole and at the ends (Fig. 5).

\section{Drilling}

The perforation techniques used to make holes in beads are one of the most important indicators of specific technological traditions. They also preserve the individual actions of the bead driller. The study of bead drill holes using silicone impressions and Scanning Electron Microscopy is a methodology that has become highly developed through experimental drilling and comparison with ancient beads (Kenoyer 2017c). The bead drill holes examined in this study were carefully cleaned and then silicone impressions were taken using vinyl polysiloxane to document the nature of the drilling and bead drill hole wear (Fig. 6). The material used is an automix system produced by $3 \mathrm{M}$ ESPE (Express ${ }^{\mathrm{TM}}$ VPS Impression Material). The impressions were studied and photographed at different magnifications using a SEM (Hitachi 570S-UW Madison Laboratory for Experimental Archaeology and IIT Gandhinagar, India). At low magnification $(20 \mathrm{X})$ it is possible to see overall drilling features, but at higher magnification (100X to $300 \mathrm{X})$ it is possible to differentiate the type of drill used and the type of internal abrasion that resulted from long periods of string wear. Using this approach, it is possible to differentiate two major types of drilling on the beads in this study: diamond drilling and drilling using a metal drill with fine abrasives.

Diamond Drilling - The earliest evidence for the drilling of hard stone beads using diamond drills and utilizing some form of bow drill has been reported from the site of Nagara (sixth to third centuries B.C.E.), an important city in the ancient bead making region of Gujarat, India (Kenoyer 2017a:138-140). Diamond has a hardness of 10 on the Mohs scale and leaves a deep jagged surface when cutting chalcedony (6.5-7 Mohs hardness). Two types of diamond drills were used in antiquity and continue to be used by traditional bead drillers at the modern city of Khambhat (Cambay), Gujarat, India. 


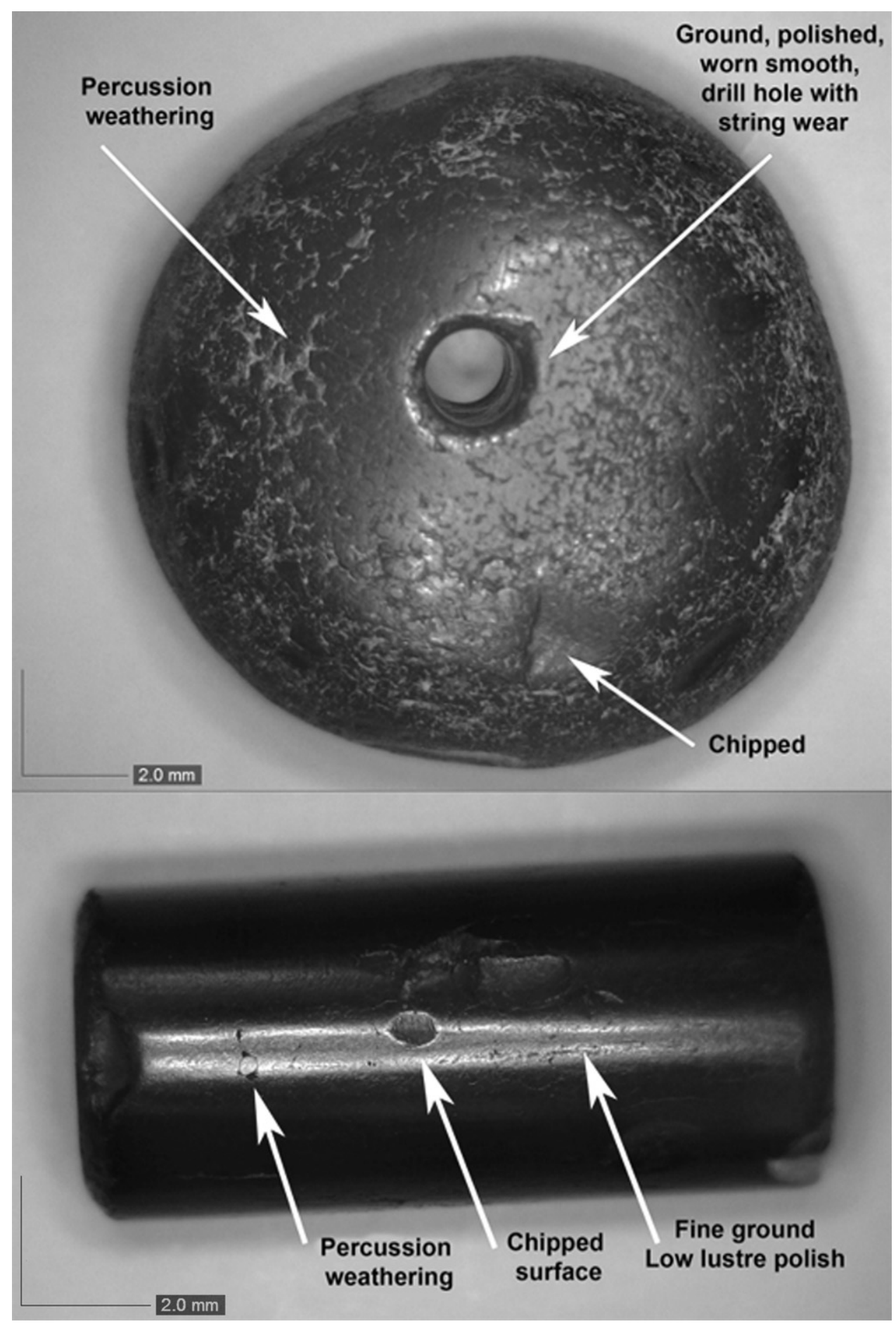

Fig. 4. External features and bead end wear: (top) short oblate bead showing chipping, percussion weathering, grinding, polishing, and use wear from rubbing against another bead; (bottom) long cylindrical bead showing chipping, percussion weathering, grinding, and polishing. 


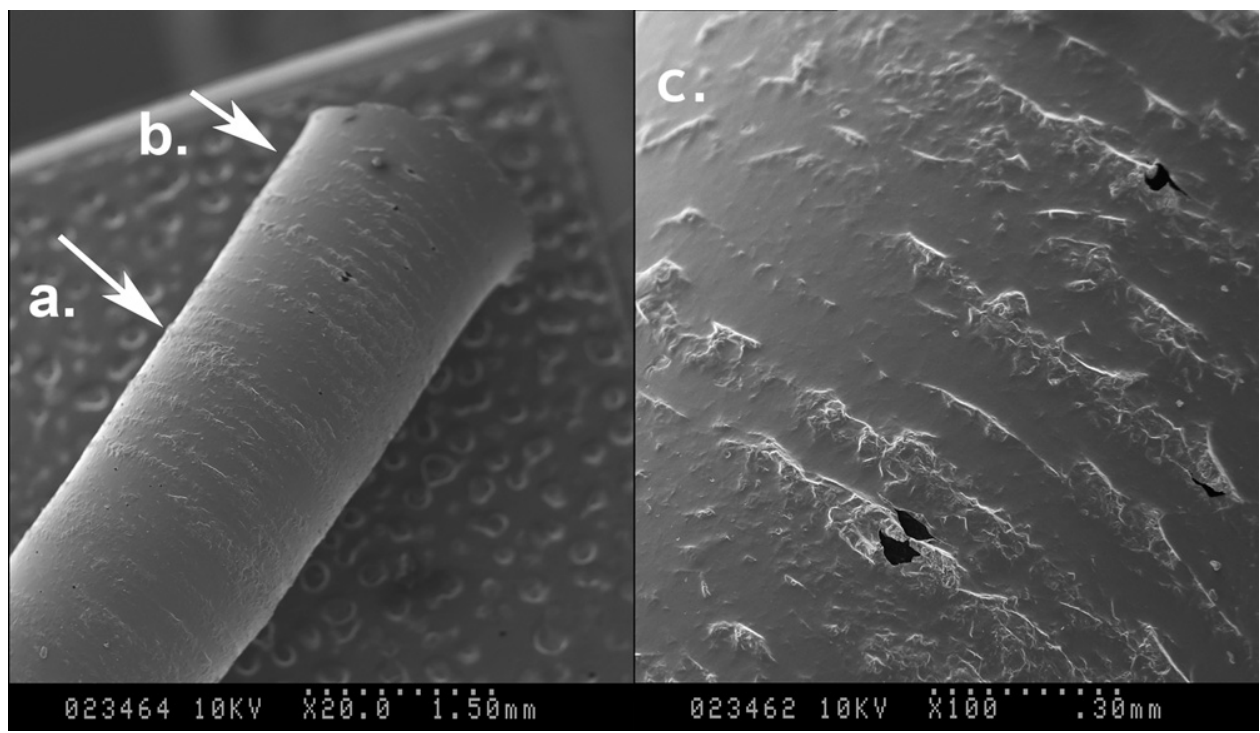

Fig. 5. Drill hole internal string wear: (a) rough striae from diamond drilling; (b) smooth polished surface from string wear; (c) close up of rough striae and smooth areas from string wear.

The single diamond drill is made by crimping a large diamond fragment at the tip of a soft iron drill bit (Fig. 7). In order to drill completely through a bead, the diamond chip must be larger than the drill shaft. This type of drilling with very narrow drills is documented in Afghanistan and parts of South Asia (Kenoyer 2017c:421, fig. 15; Kenoyer and Vidale 1992). In Khambhat, drilling using a single diamond drill with a relatively large diamond chip on the tip is called a tekni (Fig. 7a). It is not used to drill through the bead, but only to create a depression at the end of the bead so that a narrower, double diamond drill can be used to perforate the bead (Kenoyer et al. 1991:53). The double diamond drill has two tiny diamond chips crimped to the edges

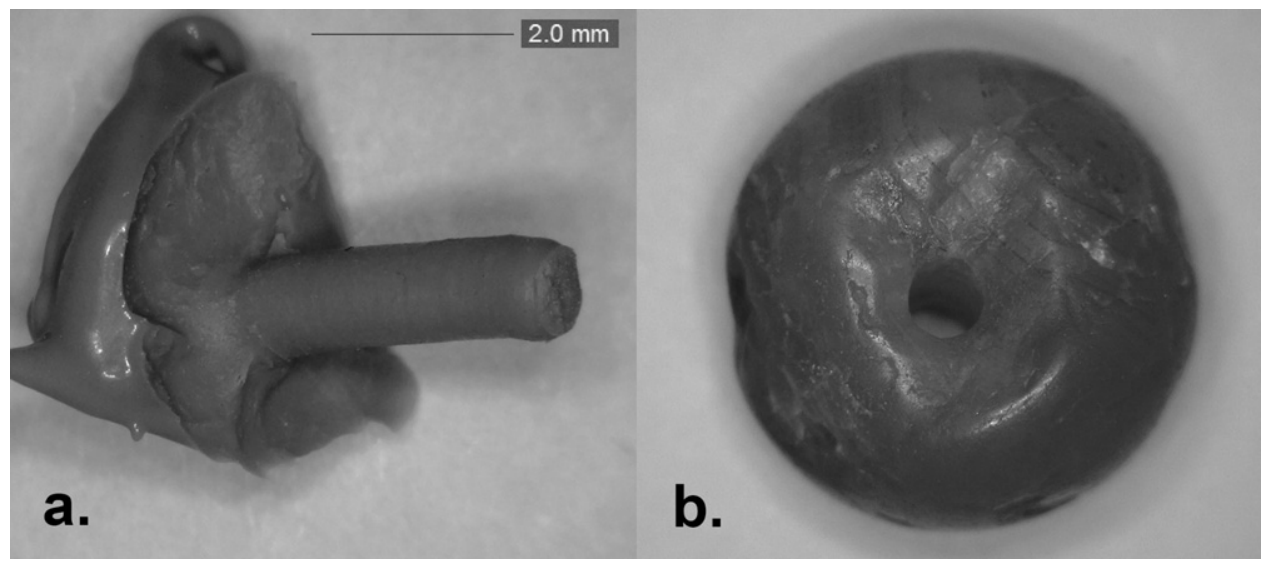

Fig. 6. Bead surface and impression used to determine manufacturing methods and use wear: (a) silicone impression of bead drill hole; (b) carnelian bead. 


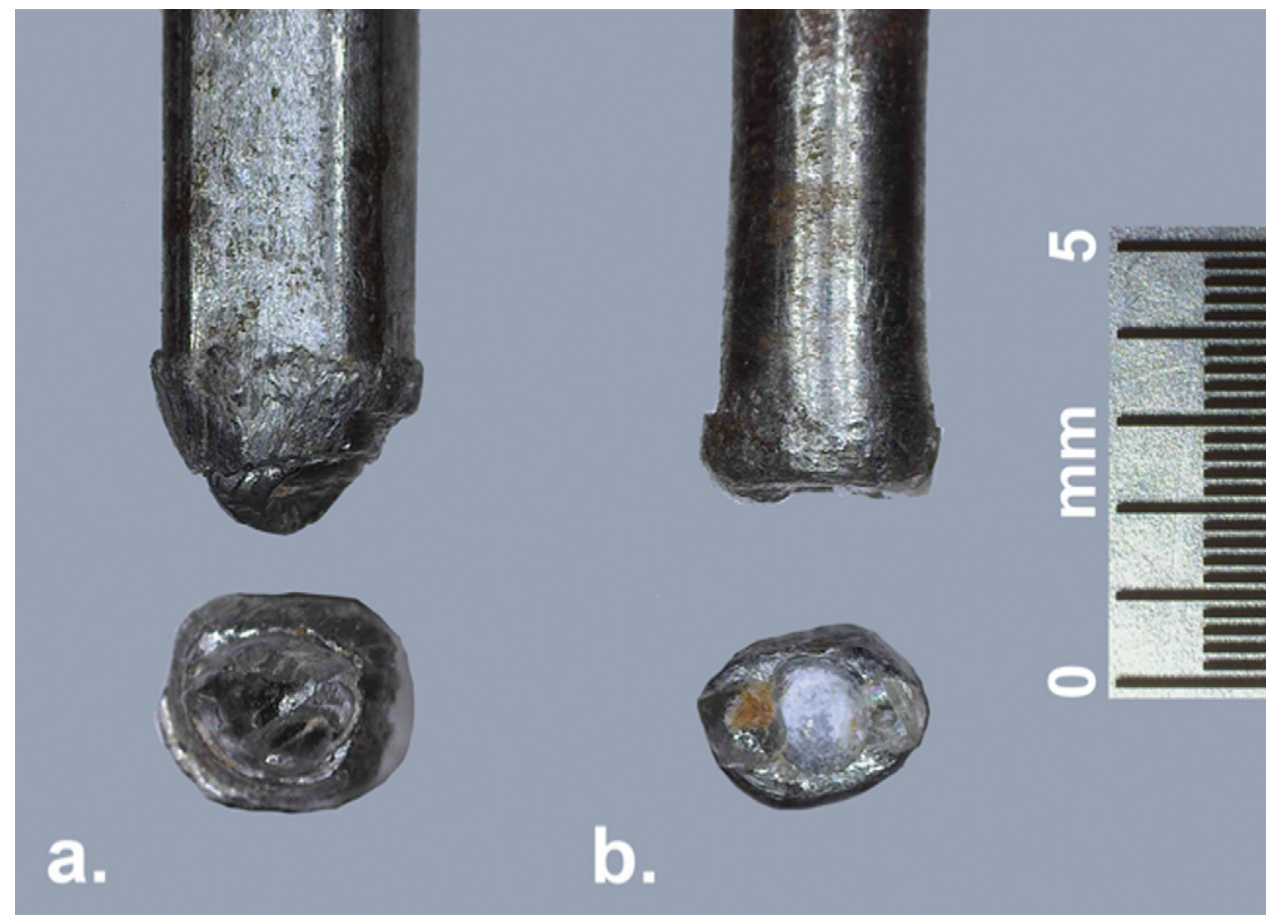

Fig. 7. Diamond drill types: (a) single diamond drill (tekni), Khambhat, India; (b) double diamond drill (sayedi), Khambhat, India.

of the tip of the drill so that they cut from the tip and one side of the diamond chips (Kenoyer and Vidale 1992:514-515, fig. 14) (Fig. 7b). The shaft of the drill bit is narrower than the width of the two diamond chips at the tip, which results in a relatively straight cylindrical drill hole with deep, parallel drilling striae that circle the drill hole (Kenoyer 2017c:421-429; Kenoyer and Vidale 1992). The identification of single and double diamond drilling is relatively obvious if the bead drill hole is fresh, but when the bead has been worn for long periods, the drill hole can become worn and polished so that only traces of the deep jagged drilling striae are visible (Fig. 5).

Beads that were perforated using a double diamond drill often have evidence for initial drilling with a single diamond drill at the very edge of the drill hole (Fig. 8a), before the remainder of the hole is perforated with a double diamond drill (Fig. 8b). If one of the diamond chips of a double diamond drill falls out, the drilling can appear slightly wavy with undulating patterns of parallel striae. When drilling a bead with a bow drill, the bead must be held in a vise and the drill held perfectly vertical to the bead in order to avoid dislodging the diamond chips and bending the drill bit. Lateral movement can result in holes that are not perfectly cylindrical, but master bead drillers were able to perforate beads with relatively straight, cylindrical holes. For long beads, it was necessary to drill halfway through the bead from one side, then turn the bead over and drill from the opposite side, with the drill hole meeting in the middle. A master bead driller would be able to orient the drill so that the holes met perfectly, but other drillers with less skill were not able to align both sides. Drilling alignment thus helps to distinguish the quality of the beads made and the skill of the bead drillers in a workshop. 


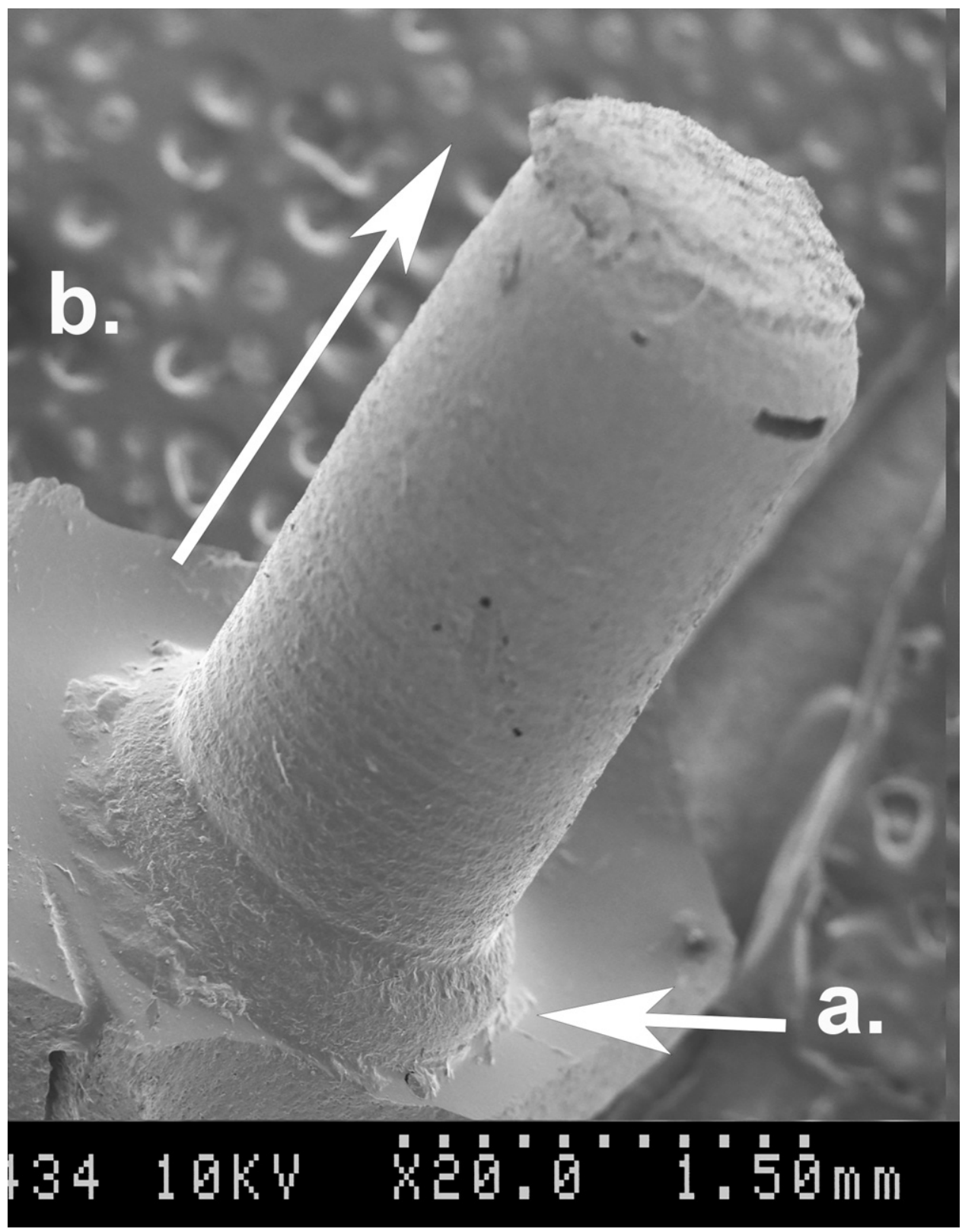

Fig. 8. Diamond drilling features seen from drill hole impressions: (a) wider drill was used to start hole; (b) narrower double diamond drill was used to complete drilling.

Short beads can also be turned over to drill from both sides, but in many cases, the drilling was done only from one side and the drilling resulted in a spall popping out from the opposite side (Fig. 9). This type of drilling leaves a very jagged edge on one side of the bead and in some cases a significant portion of the bead was broken off in the process. This technique is often done to expedite the drilling process and allows for 


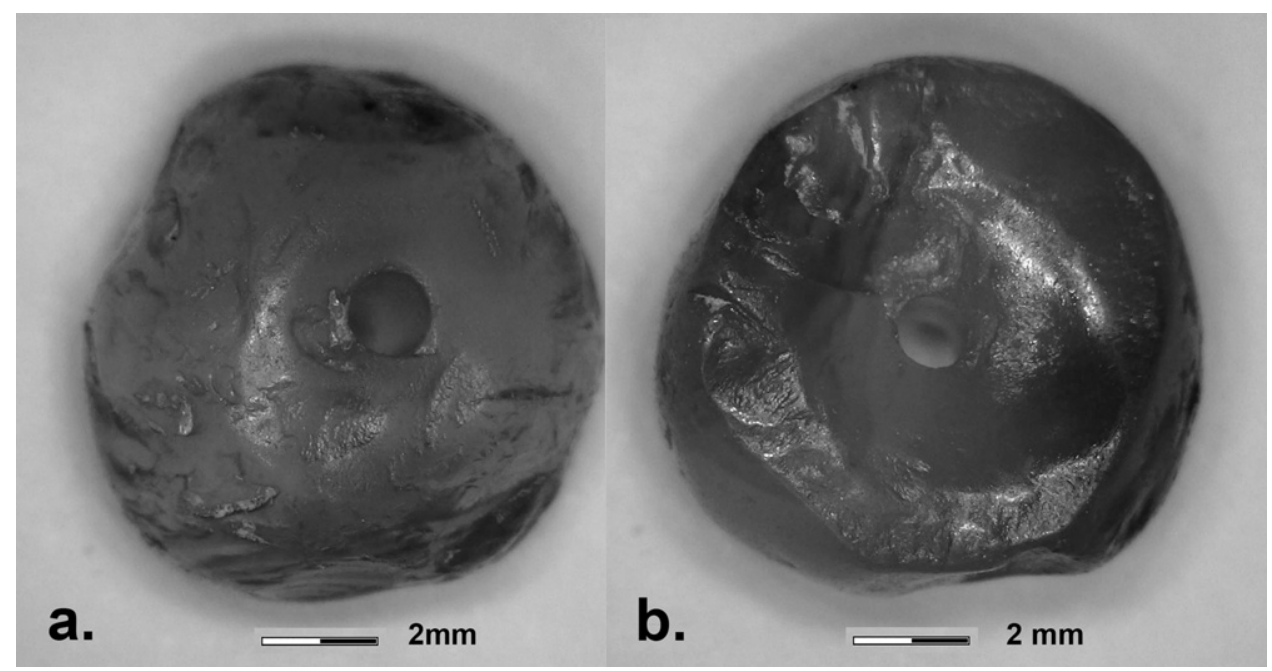

Fig. 9. Carnelian bead with one end popped out from drilling: (a) one side drilled; (b) reverse side popped out.

the rapid production of stone beads, but also usually results in lower quality beads that are imperfectly finished at one end.

Drilling with Metal and Fine Abrasive - The other major form of drilling found in this sample is drilling with a metal drill and some form of fine abrasive. This type of drilling features irregular, parallel drilling striae and undulations from the drilling process, a slight tapering of the drill hole (Fig. 10a), and faint traces of abrasion in areas where the

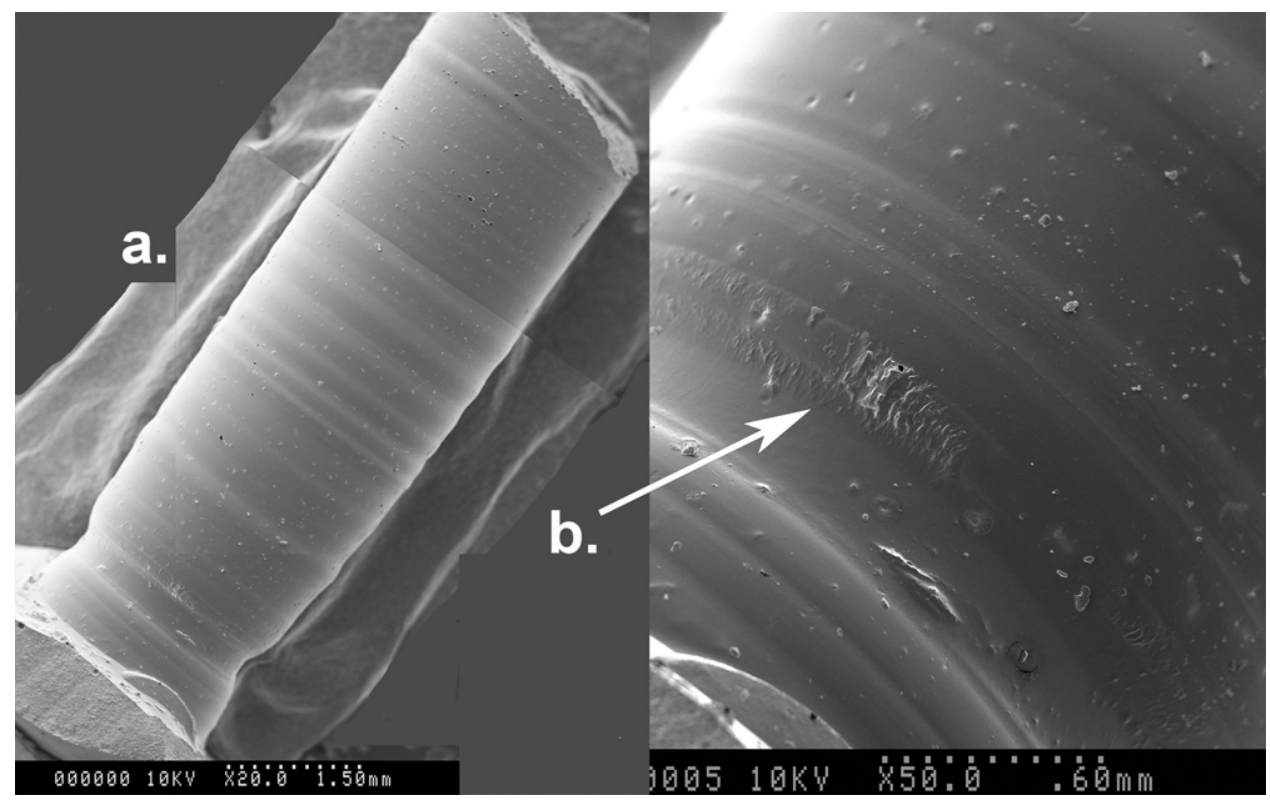

Fig. 10. Drilling with metal and fine abrasive: (a) long tapered drill hole with irregular undulating striae; (b) higher magnification showing traces of abraded surface. 


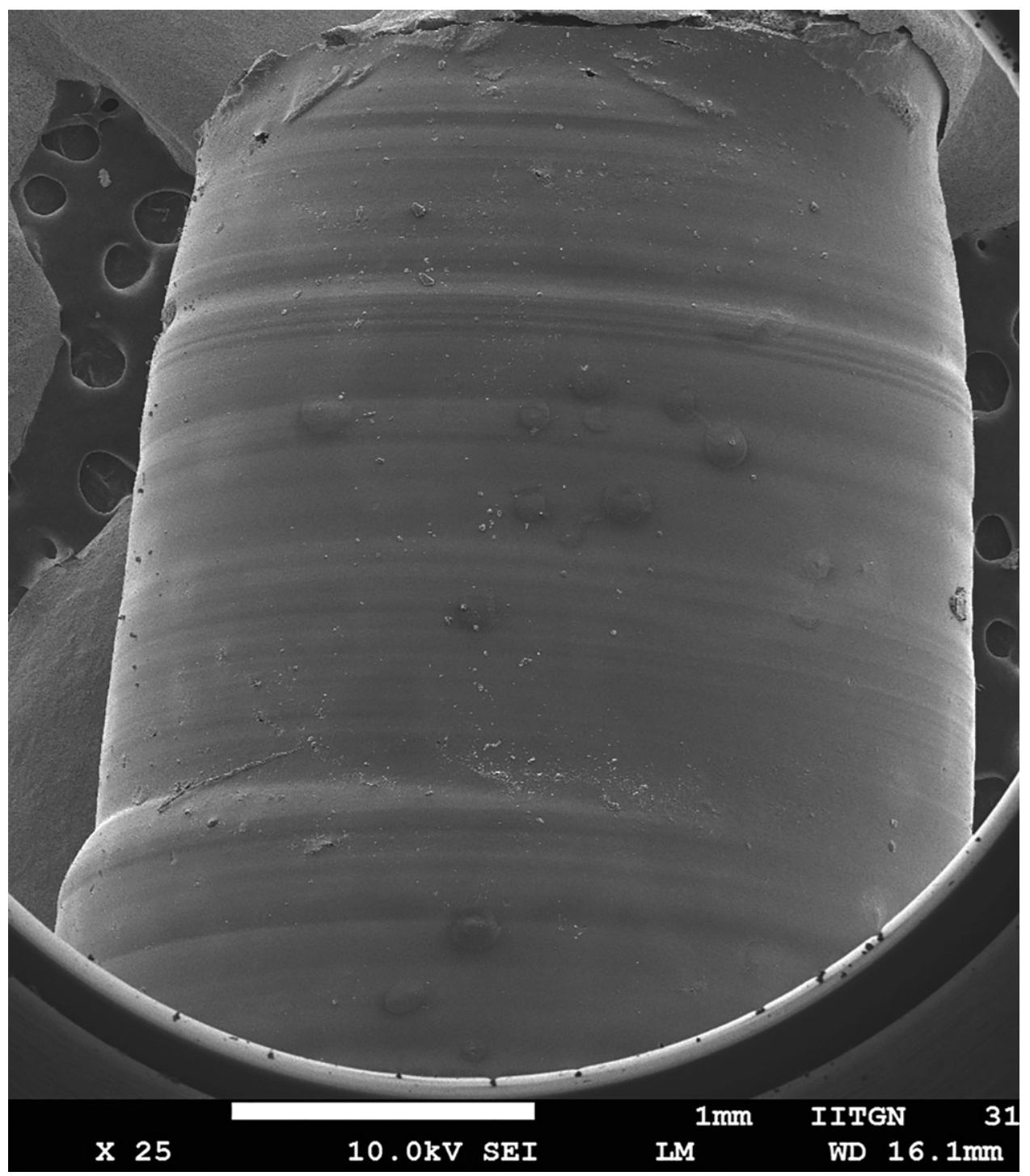

Fig. 11. Stepped and tapered cylindrical drill hole, suggesting different sizes of solid metal or possibly tubular drilling.

drilling was less intense (Fig. 10b). The shape of the metal drill could have been solid or possibly tubular in some cases; it is often difficult to differentiate these two types of drills unless the tip of the drilling is preserved. The pressure from drilling can leave collar-like protrusions or striae along the drill hole and sometimes drills are repaired or changed, resulting in a slightly smaller drill and a stepped pattern of striae (Fig. 11). The metal drill could have been made of iron or bronze, and the abrasive could have been a fine quartz or garnet (hardness 6.5-7.5 Mohs) or very fine emery or corundum (hardness 8-9 Mohs). Experimental studies are still ongoing to determine the nature of the abrasive that might have been used. The fact that the surfaces of these bead drill 
holes are highly polished indicates that the drilling process also resulted in a smooth and highly polished surface.

\section{KOREAN BEAD STUDY}

This research examined 123 stone beads from different kingdoms and regions. The 68 carnelian beads fall into a few different shapes and two major groups. As seen in Fig. 12, the shapes are: (1) irregular; (2) semi-irregular; (3) spherical; (4) faceted hexagonal; (5) cylindrical; and (6) faceted pentagonal. Irregular beads are those that were drilled, but little to no effort was made to finish shaping or polishing the beads. For semi-irregular beads, some effort was made to make the bead somewhat symmetrical and smooth and polish the outer surface. We assigned beads that had been finished very quickly (especially the smaller beads) and have irregular or semi-irregular asymmetrical shapes to the Group I category. Beads that were finished with care and deliberately formed into a specific, often facetted, shape, are referred to as Group II beads. This group includes spherical, cylindrical, faceted hexagonal, and faceted pentagonal beads.

Although this study is not a comprehensive survey of carnelian beads of the Korean peninsula, we note a few general trends. Late Proto-Three Kingdoms period (C.E. 1-300) carnelian beads are predominantly Group I types, having irregular or semiirregular shapes. This type of bead persists into the Three Kingdoms period, but is joined by Group II carnelian beads, especially in the southern kingdoms of Silla and Kaya. Late Paekche beads were not examined, but this trend towards better quality beads may have continued there as well.

In terms of carnelian beads on the peninsula, 68 beads represent only a small fraction of carnelian beads utilized during the Late Proto Three Kingdoms period and Three Kingdoms period. The Osan Such’ŏng-dong (RR: Suncheong-dong) site, a fourth to

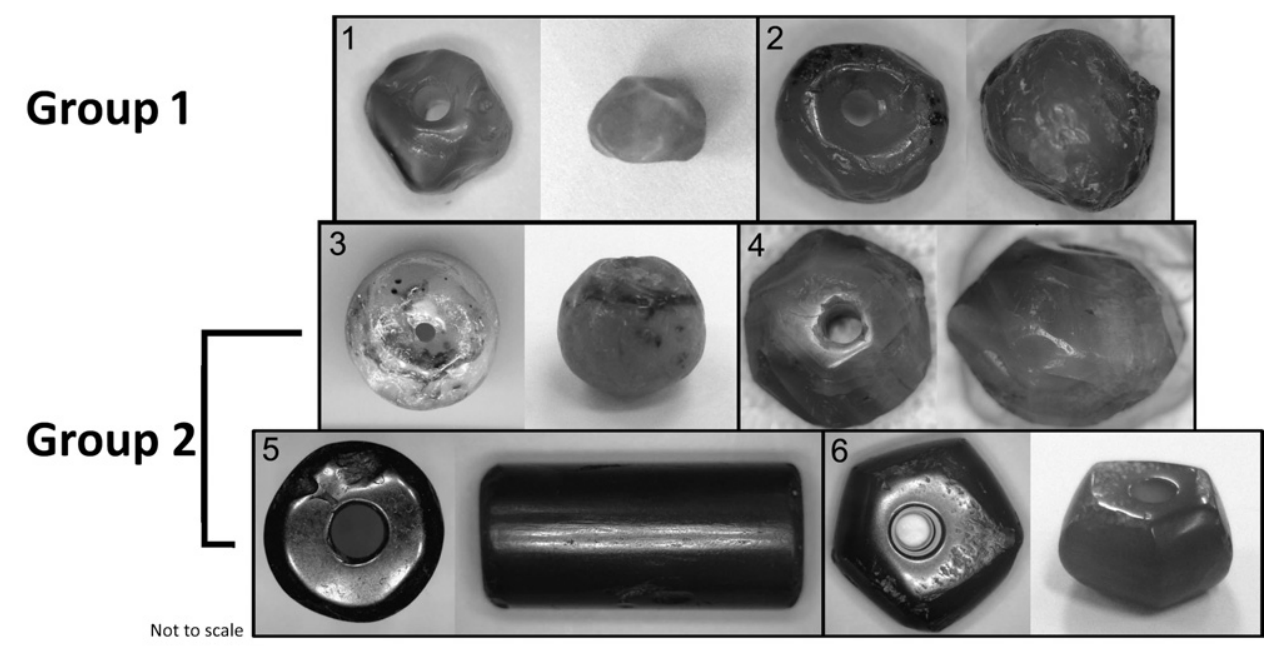

Fig. 12. Examined Korean carnelian bead types: (1) irregular spherical, early Paekche bead; (2) semiirregular spherical, Paekche bead; (3) spherical, Silla bead; (4) faceted hexagonal bicone, Silla bead; (5) long cylindrical, early Paekche bead; (6) faceted pentagonal barrel, early Paekche bead. 


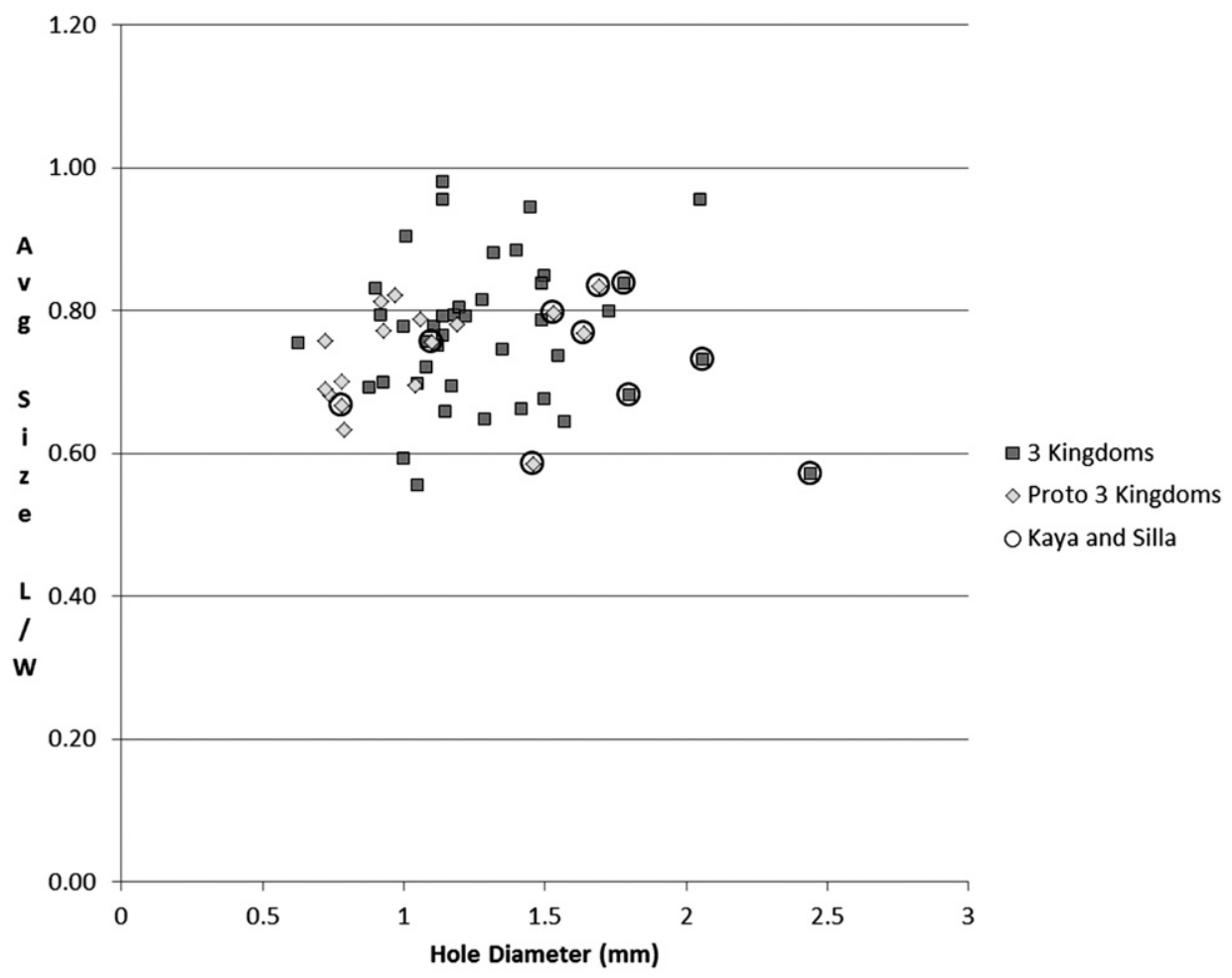

Fig. 13. Diamond drilled beads over time and space, with diamond-drilled carnelian bead size (L/W) compared to hole diameter ( $\mathrm{mm}$ ) over time.

fifth century Paekche cemetery, yielded 4000 stone beads, the majority of which were carnelian (Kyŏnggi 2012:59). Group I carnelian beads are often found on Proto-Three Kingdoms Paekche sites near Seoul and then become more prominent over time (as at Osan Such'ŏng-dong). In the southern Kaya and Silla regions, carnelian shows up in small amounts at the end of the Proto-Three Kingdoms period and blossoms into popularity in the Three Kingdoms period. Necklaces made up primarily of bead types 3 (spherical) and 4 (faceted hexagonal) are found in both Silla and Kaya. These necklaces, which appear in the Gyeongju National Museum and the Gimhae National Museum, are made up of 22 to 45 Group II carnelian beads of roughly the same or graduating sizes. Beads are small and easy to transfer over long distances, but the thousands of beads and specific shapes points to a large and deliberate trade network over time.

In order to investigate manufacturing styles and technology, the bead shape, measurements, stone type, manufacturing quality, and drill hole size and shape were recorded. Specific Gravity testing was performed on some beads in order to confirm that they were carnelian. The size of the bead, measured by length divided by width, was compared to drill hole diameter to discern different manufacturing trends over time and potential different workshops (Fig. 13). The main assumption is that workshops wherein specialized bead makers and drillers were producing large numbers of beads will present less variation in bead shape and drill diameters than those from unrelated workshops. This assumption is based on observations of bead makers and 


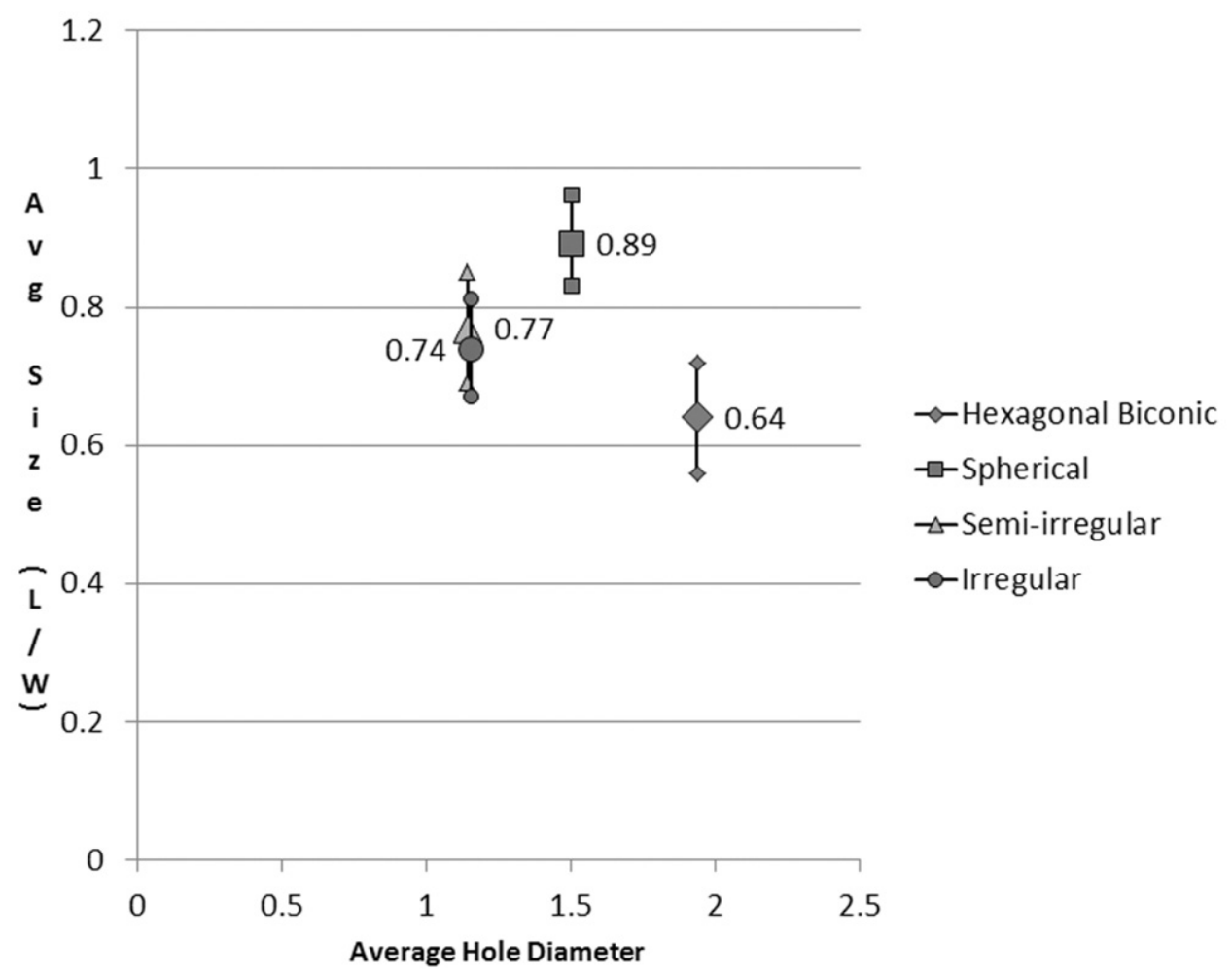

Fig. 14. Average bead size compared to average hole diameter grouped by bead type (with standard deviation).

drillers in Khambhat, India and the analysis of archaeological samples (Kenoyer et al. 1994:286-291, 304) and is strongly supported through recent studies involving Elliptical Fourier Transform analysis, a statistical analysis used to compare shapes that has been recently applied to beads from known workshops in Khambhat, India, and to archaeological bead assemblages (Ludvik 2018:33-52).

The Proto-Three Kingdoms period beads examined here are almost all small in size and hole diameter. The four beads that are the exception to this rule are all from the Silla or Kaya regions, suggesting that the south of the peninsula was acquiring beads from a different workshop or source than the Paekche region during the Proto-Three Kingdoms period. The sizes of Three Kingdoms period beads are more spread out, with a general move towards larger beads and drill hole sizes. However, many of the Paekche beads still fall into a small diameter to size ratio. This may be partially because the majority of the Paekche beads date to the early or middle Three Kingdoms period; they may be Proto-Three Kingdoms period beads which were obtained at the end of the period but not deposited until the early Three Kingdoms period. This is supported by comparing the average hole diameter and bead size of Group I beads from both time periods (Fig. 14). Whereas the mean drill hole diameter of Proto-Three Kingdom beads is $1.12 \mathrm{~mm}$, the mean diameter of the Three Kingdoms period bead drill holes is $1.33 \mathrm{~mm}$, showing a general increase in drill hole size over time. 
All of the Kaya and Silla Three Kingdoms period carnelian beads show larger hole sizes and larger bead sizes in general (Fig. 13). Silla and Kaya are also the source of the majority of bead type 4, the faceted hexagonal, which does not resemble carnelian beads in Southeast Asia or China, but does resemble beads from South and Central Asia. Both spherical and faceted hexagonal beads show a distinctly different bead size to hole size ratio compared to Group I irregular and semi-irregular beads (Fig. 14). More Silla and Kaya carnelian beads need to be examined before coming to any conclusions, but these initial findings support the idea that the various polities were utilizing different, if occasionally overlapping, trade sources and routes.

More data are needed to determine where these carnelian beads were manufactured and how they made their way to the Korean peninsula. Carnelian beads similar to those found in Korea were manufactured in many different parts of South Asia, but there is also some evidence to suggest that from around C.E. 100, some beads may have been made in Southeast Asia, particularly Thailand, by South Asian craftspeople or those trained in South Asian techniques (Bellina 2014:365-368; Carter 2015:735). The raw material for the Southeast Asian beads most likely came from South Asia based on its resemblance to high quality South Asian carnelian and the vast quantity found in the archaeological record. There is some evidence that multiple sources of carnelian were being used to manufacture beads (Theunissen et al. 2000:101-102), but more recent studies suggest the majority of carnelian in Southeast Asia was not from Southeast Asian sources (Carter 2015:735). Evidence for South Asian (ancient Indian) craftspeople using South Asian techniques to manufacture stone beads in specifically commissioned styles for local elites has been found at the site of Khao Sam Kaeo, Thailand (Bellina 2003:291, 2014:367; Carter 2015:735). Recently examined Southeast Asian beads confirm that they were manufactured using diamond drills (Carter 2015:741). Furthermore, drill hole sizes grow larger over time in both the Southeast Asian and Korean peninsular beads (Carter 2015:741). However, from around 500 B.C.E.-C.E. 500, the trend for South Asian style beads in Southeast Asia is the exact opposite of what we see in the Korean peninsula. Carnelian beads in Cambodia and Thailand shift from good quality, well-constructed beads (Group II) to mass produced, poorly finished beads (Group I) (Carter 2015:739). It is possible that the advent of local mass production of beads in Southeast Asia meant that South Asian craftspeople and traders expanded their markets for quality stone beads further afield. Both South and Southeast Asian carnelian bead shapes do include asymmetrical, irregular, and spherical beads (Carter 2015:740; Kelly 2013:101, 122), so it is difficult to determine if South Asian craftspeople, either in South Asia or in Southeast Asia, were constructing carnelian beads specifically for the Three Kingdoms period market.

It is important to note that ten of the Korean carnelian beads from Group 1 were manufactured using a larger single diamond drill to make a depression before switching to a narrower double-diamond drill (Fig. 15). This is identical to the techniques still used in Khambhat and Nagara, Gujarat, India today. The difference in size between the larger and smaller drills used on these beads is between 0.2 and $0.5 \mathrm{~mm}$, with an average of $0.4 \mathrm{~mm}$, suggesting relatively standardized drill sizes utilizing South Asian manufacturing techniques.

There are some comparable examples in Southeast Asia (Bellina 2014:356) to the short, faceted hexagonal carnelian beads that are prominent in the Kaya and Silla polities (Fig. 12, Group 2, type 4). In ongoing research on beads in Sri Lanka, Amalka Wijesuriya Juwanwapu has identified various types of faceted carnelian beads from 


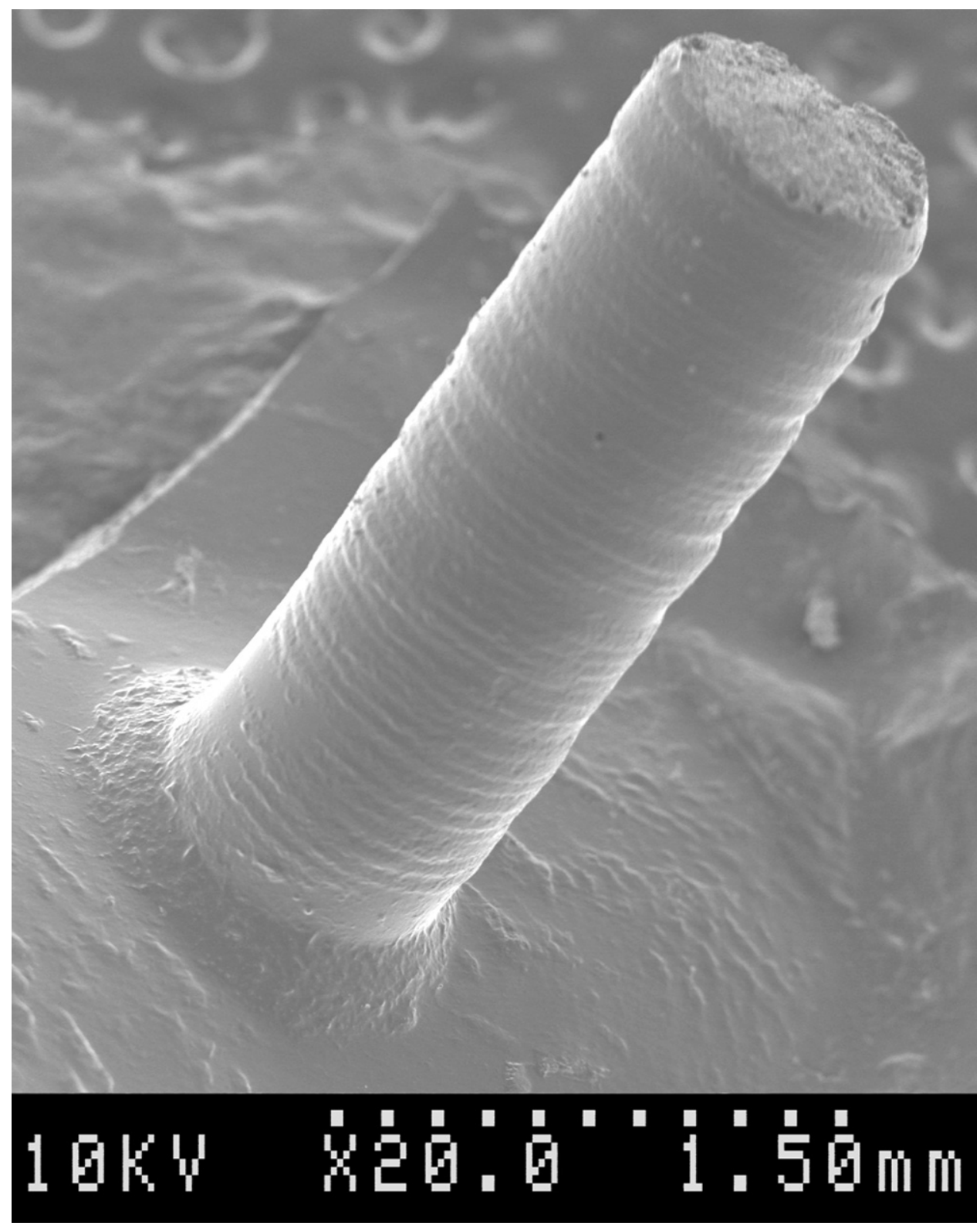

Fig. 15. Drill hole impression of a Paekche carnelian diamond-drilled bead, drilled first with a single double diamond drill, then a smaller double-diamond drill.

offerings at the Neelagiri Stupa in Sri Lanka from the third century B.C.E. through the seventh century C.E. (Wijesuriya Juwanwapu and Kenoyer pers. comm. 2016). However, this bead type is also quite common in South Asia and Central Asia (Kenoyer pers. observation; Rienjang et al. 2017), so it is possible that the beads in Korea were passing over different routes to reach the peninsula. South Asian diamond drilled beads from this time period must be examined to see if the trend continues there as well. 
In contrast to the diamond-drilled carnelian beads, the cylindrical beads were drilled using metal and fine abrasives and were made from a carnelian raw material that is more transparent and either a much deeper red or a lighter yellow-orange color. These beads were deposited over a period of centuries, but show a consistency in drill hole size (2.5-3 mm with one outlier). It is possible that these beads were all originally produced in similar workshops in one time period, but then passed down for many generations and gradually put into tombs. Fig. 10a shows a bead that was drilled from both sides but has been heavily worn away on one end and broken on the other, suggesting years of heavy usage before final deposition. It could also mean that the drill sizes used to produce beads did not change for hundreds of years and that the same workshops continued to produce beads that were traded to the Korean peninsula in a continuous pattern that lasted for many centuries. Although a single, non-carnelian bead from Japan has been found in a tomb with evidence of metal drilling with fine abrasive (ongoing study by Glover), there is no evidence from workshop sites in Korea or Japan that metal drilling with fine abrasive was used during this time period. In ongoing research, Kenoyer has identified several potential carnelian sources across mainland East Asia, northern South Asia, and Central Asia from which these beads could have been made. The uniformity in size, shape, and manufacturing method points to at least one organized workshop. The heavy wear on the ends of the beads and the way they were often broken and reworked suggests these beads were held onto for quite some time before being deposited in Paekche graves.

In China during the Western Han Dynasty (206 B.C.E.-C.E. 8), non-jadeite and nephrite semi-precious stones became commonly traded (Barnes 1999:204). The transparent, dark red to light yellow-orange color and different manufacturing methods of the carnelian cylinder beads (bead type 5) suggests that they derive from a different raw material source than the diamond drilled beads. Although this shape is occasionally found in Southeast Asia, this type of bead is relatively common in Yunnan during the Western Han dynasty (Yunnan 2006:71). More research is needed to sort out the sourcing of this type of bead.

The faceted pentagonal bead seen in Fig. 12 (Group 2, type 6) was also perforated using a metal drill with fine abrasive and the facets seem to have been heavily polished, resulting in rounded edges rather than the sharp edges present on many of the faceted hexagonal beads. This bead may have been made to resemble the faceted beads coming from South or Southeast Asia, but it is also possible that it represents a totally different workshop tradition. In terms of raw material color, this bead is more brown-orange than red-orange. Since it is possible to use chemical analysis to source carnelian (Carter and Dussubieux 2016; Law et al. 2013), hopefully future studies of Korean carnelian beads will include some form of this analysis.

\section{CONCLUSION}

Carnelian beads were imported into the Korean peninsula in large numbers during the Proto-Three Kingdoms period and the Three Kingdoms period. The majority of these beads were produced using diamond drills. They were manufactured using distinctive South Asian drilling technology by craftspeople in South Asia or Southeast Asia. The raw material for these beads probably came from South Asia as well, since carnelian from other sources in East Asia would not have been diamond drilled and the carnelian resembles South Asian carnelian. This increase in South Asian style beads 
parallels the rising number of imported glass beads from these regions documented by Pak (2016:172). Quickly manufactured, roughly shaped beads of Group I dominated during the Proto-Three Kingdoms period. These beads persisted into the Three Kingdoms period, but were joined by Group II beads which are more finely made and of better quality. Although more Silla and Kaya beads need to be examined, there is a distinct difference between drill hole sizes, bead sizes, and bead morphology from Paekche compared to Silla and Kaya beads. This points to these polities utilizing different trade routes supplied by different workshops to obtain their carnelian beads.

Currently, we are examining a selection of diamond drilled beads from South Asia dating to the same general time period to determine if any of the Korean peninsular beads can be assigned to specific South Asian regional workshops. The Three Kingdoms polities also acquired a small amount of carnelian beads from elsewhere, which were manufactured with metal drills and fine abrasive. Both the diamonddrilled and metal drilled beads show signs of wear pointing to the beads being worn for quite some time before being deposited in tombs. The elites of the Korean peninsula during this time period were going to extreme lengths to obtain carnelian beads, while ignoring locally available sources of raw material for other types of beads. Obtaining these foreign beads would have required extensive economic networks and were probably important indicators of status, wealth, and power among the elites of each polity. Their presence as ritual deposits under temples also suggests that some aspect of the carnelian beads, be it color or shape, was ideologically important to elites.

This study is still in its preliminary stage, so it is likely that some of our initial interpretations will be refined and expanded with more data and new forms of analysis. We are also planning to examine a wider variety of beads and kogok 曲玉 (RR: gogok) made of carnelian, rock crystal, amethyst, and other types of raw material in order to develop a more comprehensive documentation of interregional and international trade in these semi-precious commodities.

\section{ACKNOWLEDGEMENTS}

We would like to thank the many scholars who provided access to their collections and the institutions that allowed the first author to study the beads and take impressions. Special thanks to the Seoul National University Museum, Bokcheon Museum, Seoul Baekje Museum, Busan National University Museum, SungLim Institute of Cultural Properties, Gukbang Cultural Heritage Institute, Central Institute of Cultural Heritage, Korea University Museum, Kyungpook University Museum, Gyeore Institute of Cultural Heritage, Gyeonggi Cultural Heritage Research Institute, and Busan Museum. Major funding for this study was provided by a Fulbright Korean-American Educational Commission award to the first author and the generous support of the University of Wisconsin-Madison Anthropology Department for use of the SEM. We also want to thank the Director and staff at the Indian Institute of Technology, Gandhinagar for the use of their SEM to image some of the samples.

\section{REFERENCES CITED}

Appadurai, Arjun

1988 The Social Life of Things: Commodities in Cultural Perspective. Cambridge: Cambridge University Press.

Baines, John, and Norman YoffeE

2000 Order, legitimacy and wealth: Setting the terms, in Order, Legitimacy and Wealth in Ancient States: 13-20, ed. J. Richards and M. V. Buren. Cambridge: Cambridge University Press. 
BARNES, GinA

1999 The Rise of Civilization in East Asia: The Archaeology of China, Korea, and Japan. London: Thames and Hudson.

BELLINA, BÉRÉNICE

2003 Beads, social change and interaction between India and South-east Asia. Antiquity 77:285-297.

2014 Maritime silk roads' ornament industries: Socio-political practices and cultural transfers in the South China Sea. Cambridge Archaeological Journal 24(03):345-377.

Carter, Alison K.

2015 Beads, exchange networks and emerging complexity: A case study from Cambodia and Thailand (500 BCE-CE 500). Cambridge Archaeological Journal 23(4):755-757.

Carter, Alison K., and Laure Dussubieux

2016 Geologic provenience analysis of agate and carnelian beads using laser ablation-inductively coupled plasma-mass spectrometry (LA-ICP-MS): A case study from Iron Age Cambodia and Thailand. Journal of Archaeological Science: Reports 6:321-331.

Chungang Munhwajae Yŏn'Guwŏn 중앙문화재연구원 [Central Institute of Cultural HeritaGe]

2013 Osan Kwŏl-dong yujŏk 1-ho kuhoek chŏt'aek 1-ho suhyŏl yugu Osan Segyo 2-chigu t'aekchi kaebal saŏmnae (1 5-chijŏm) 烏山 閶洞遺蹟 1호 구획저택 1호 수혈유구 오산 세교2지구 택지개발 사업내 (1 5지점) [Osan Ruins Boundary 1, Osan Segyo District Residential Development Project (1-5branch)]. Sŏngnam: Chungang Munhwajae Yŏn'guwŏn.

EARLe, Timothy

1994 Wealth finance in the Inka Empire: Evidence from the Calchaqui Valley, Argentina. American Antiquity 59(3):443-460.

Farrington, Oliver C., and Berthold Laufer

1927 Agate: Physical Properties and Origin and Archaeology and Folk-lore. Chicago: Field Museum of Natural History.

Helms, Mary W.

1993 Craft and the Kingly Ideal: Art, Trade, and Power. Austin: University of Texas Press

KeLly, GWen

2013 Craft Specialization, Technology and Social Change: A Study of Material Culture in Iron Age and Early Historic South India (c. 1200 BCE-400 CE). Ph.D. diss. University of WisconsinMadison.

KENOYER, JONATHAN M.

1995 Ideology and legitimation in the Indus State as revealed through symbolic objects. The Archaeological Review: Pakistan Archaeologists Forum 4(1\&2):87-131.

2000 Wealth and socio-economic hierarchies of the Indus Valley Civilization, in Order, Legitimacy and Wealth in Early States: 90-112, ed. J. Richards and M. van Buren. Cambridge, UK: Cambridge University Press.

2003 Stone beads and pendant making techniques, in A Bead Timeline: Vol. 1 Prehistory to 1200 CE: 14-19, ed. J. W. Lankton. Washington, DC: The Bead Museum.

2005 Bead technologies at Harappa, 3300-1900 BC: A comparison of tools, techniques and finished beads from the Ravi to the Late Harappan Period, in South Asian Archaeology 2001, vol. 1: 157-170, ed. C. Jarrige and V. Lefevre. Paris: CNRS.

2017a History of stone beads and drilling: South Asia, in History, Science \& Technology of Stone Beads: 125-148, ed. A. Kanungo. Ahmedabad: Indian Institute of Technology, Gandhinagar \& Aryan Press.

$2017 b$ Stone beads of the Indus Tradition: New perspectives on Harappan bead typology, technology and documentation, in History, Science E Technology of Stone Beads: 149-164, ed. A. Kanungo. Ahmedabad and Delhi: Indian Institute of Technology, Gandhinagar \& Aryan Press.

2017c Using SEM to study stone bead technology, in History, Science \& Technology of Stone Beads: 405-433, ed. A. Kanungo. Ahmedabad and Delhi: Indian Institute of Technology, Gandhinagar \& Aryan Press.

KenOyer, Jonathan M., AND M. Vidale

1992 A new look at stone drills of the Indus Valley Tradition, in Materials Issues in Art and Archaeology III: 495-518, ed. P. Vandiver, J. R. Druzick, G. S. Wheeler and I. Freestone. Materials Research Society Symposium Proceedings, vol. 267. Pittsburgh: Materials Research Society. 
Kenoyer, Jonathan M., Massimo Vidale, and Kuldeep Kumar Bhan

1991 Contemporary stone bead making in Khambhat India: Patterns of craft specialization and organization of production as reflected in the archaeological record. World Archaeology 23(1):44-63.

1994 Carnelian bead production in Khambhat India: An ethnoarchaeological study, in Living Traditions: Studies in the Ethnoarchaeology of South Asia: 281-306, ed. B. Allchin. New Delhi: Oxford and IBH.

KukPang Munhwajae YŎN'GUWŎN 국방문화재연구원 [Gukbang Cultural Heritage Institute] 2015 Sŏngnam Yŏju Poksŏn chŏnch'ŏl che-9 konggunae yujŏk 성남 여주 복선전철 제9공구내 유적 [Ruins in Sŏngnam-Yŏju, Subway Line 9]. Yŏju: Kukpang Munhwajae Yŏn'guwŏn.

Kungnip Munhwajae Yŏn'Guso 국립문화재연구소 [NATIOnAl Research Institute of Cultural HeRitAge]

1993 Hwangnam taech'ong nambun palgul chosa pogoso 황남대총 남분발굴조사보고서 [Research Report on the Southern Tomb of Hwangnam]. Seoul: Kungnip Munhwajae Yŏn'guso.

Kwon, OH Young [Kwŏn OYŎNG]

2008 The influence of recent archaeological discoveries on the research of Paekche history, in Early Korea: Reconsidering Early Korean History Through Archaeology vol. 1: 65-112, ed. M. E. Byington. Cambridge, MA: Korea Institute-Harvard University.

KyŎNGBUK TAEHAKkYO PANGMUlgWAN 경북대학교박물관 [KYUngPOOK NATIONAL UnIVERSITY MuSEUM]

2000 Yujŏk palgul 40-yŏn 유적발굴40년 [40 Years of Site Excavation]. Taegu: Kyŏngbuk Taehakkyo Pangmulgwan.

KyŎNGgI Munhwajae Yŏn'Guwŏn 경기문화재연구원 [GYeOngGi Cultural Heritage Research INSTITUTE]

2012 Osan Such’ŏng-dong Paekche punmyogun I-V 烏山 水淸洞 百濟 墳墓群 I-V [Osan Such'ŏngdong Paekche Cemetery]. Suwŏn: Kyŏnggi Munhwajae Yŏn'guwŏn.

KYŎRE Munhwa Yusan YŎN'GUWŎN 겨레문화유산연구원 [GyeOre Institute OF Cultural Heritage]

2013 Osan Ch’ŏnghak-dong yujŏk 오산 청학동 유적 [The Site of Osan Ch’ŏnghak-dong]. Koyang: Kyŏre Munhwa Yusan Yŏn'guwŏn.

Law, Randall W., Alison Carter, K. Bhan, Arun Malik, and Michael D. Glascock

2013 INAA of agate sources and artifacts from the Indus, Helmand, and Thailand Regions, in South Asian Archaeology 2007: 177-184, ed. D. Frenez and M. Tosi. Oxford: Archaeopress.

LESURE, Richard

1999 On the genesis of value in early hierarchical societies, in Material Symbols: Culture and Economy in Prehistory. Occasional Papers vol. 26: 23-55, ed. J. Robb. Carbondale: Center for Archaeological Investigations, Southern Illinois University.

LUDVIK, G. E.

2018 Hard Stone Beads and Socio-Political Interaction in the Intermediate Bronze Age Southern Levant, ca. 2500-2000 BCE. Ph.D. diss. University of Wisconsin, Madison.

NELSON, SARAH

1993 The Archaeology of Korea. Cambridge, UK: Cambridge University Press.

PAK CHUNYǑNG 박준영

2016 Han'guk kodae yuri kusŭl ŭi saengsan kwa yut'ong e nat'anan chŏngch'i sahoejŏk maek 한국 고대 유리구슬의 생산과 유통에 나타난 정치사회적 맥 [Political and societal context revealed through the production and distribution of ancient Korean glass beads]. Han'guk kogo hakpo 韓國考古學報 100:134-173.

Park, Cheun Soo [Pak Ch'ŎNSU]

2008 Kaya and Silla in archaeological perspective, in Early Korea: Reconsidering Early Korean History Through Archaeology, vol. 1: 113-153, ed. M. E. Byington. Cambridge, MA: Korea InstituteHarvard University.

POKCH'ŎN PANGMUlgWAN 복천박물관 [BOKCHEON MusEum]

$2013 a$ Han'guk sŏngsa kodae ŭi ongmunhwa yŏn'gu 한국 성사 고대의 옥문화 연구 [A Study on the Ancient Beads Culture in Korea]. Pusan: Sinhŭng Kihoek.

$2013 b$ Ok ŭi segye 옥의 세계 [The World of Ancient Beads]. Pusan: Dain Communications. 
Pough, Fredrick H.

1988 Rocks and Minerals. Boston: Houghton Mifflin Co.

Pusan Pangmulgwan 釜山博物館 [Busan Museum]

2014 Yónsan-dong M3-hobun 蓮山洞 M3 號墳 [Yŏnsan-dong Tomb M3], vol. 41. Pusan: Pusan Pangmulgwan.

Pusan Taehakkyo Pangmulgwan 釜山大學校博物館 [Pusan National University Museum]

1988 Pusan Nop'o-dong yujŏk 釜山老國洞 遺蹟 [Pusan Nop'o-dong Site]. Pusan: Pusan Taehakkyo Pangmulgwan.

2012 Pokch'ŏn-dong kobun'gun IV 福泉洞古墳群 IV [Tombs at Pokchŏn-dong, Tomb No. 35-36], vol. 37. Pusan: Pusan Taehakkyo Pangmulgwan.

RENFEW, COLIN

2012 Systems of value among material things: The nexus of fungibility and measure, in The Construction of Value in the Ancient World: 249-260, ed. J. K. Papadopoulos and G. Urton. Los Angeles: Cotsen Institute of Archaeology Press.

Rienjang, Wannaporn K., J. M. Kenoyer, and Margaret Sax

2017 Stone beads from the relic deposits: A preliminary morphological and technological analysis, in Charles Masson and the Buddhist Sites of Afghanistan. Explorations, Excavations, Collections 1833-1835: 52-57, ed. Elizabeth Errington. London: British Museum Press.

Schortman, Edward M., and Patricia A. Urban

2004 Modeling the roles of craft production in ancient political economies. Journal of Archaeological Research 12(2):185-226.

SŎNGNim Munhwajae YŎN'GUWŎN 성림문화재연구원 [Sunglim Cultural Property Research CENTER]

2014 Ulchin Tǒkch’ŏn-ni Silla myogun I-II 蔚珍德川里新羅墓群 I -II [The Ancient Site at Deokcheon-ri I-II]. Kyŏngju: Sŏngnim Munhwajae Yŏn'guwŏn.

TAKAHASHI KOJI 高橋 浩二

2012 Kofun jidai ni okeru hisui magatama no seisan to ryūtsū katei ni kansuru kenkyū 古墳時代における ヒスイ勾玉の生産と流通過程に関する研究 [Research on the Production and Distribution of Jade Magatama of the Kofun Period]. Toyama: Toyama Daigaku 富山大学.

Theunissen, Robert, Peter Grave, and Grahame Bailey

2000 Doubts on diffusion: Challenging the assumed Indian origin of Iron Age agate and carnelian beads in Southeast Asia. World Archaeology 32(1):84-105.

YunNAN SHIZHAISHAN

2006 Yunnan jinning shizhaishan chutu wenwu jingcui 云南晋宁石寨山出土文物精粹 [Ancient Dian Capital Sight-Seeing: Unearthed Artifacts from the Succinct Collection of Shizhaishan in Yunnan]. Kunming: Yunnan Ethnic Publishing House. 